\title{
Evaluating Digital PCR for the quantification of human genomic DNA: Accessible amplifiable targets
}

\author{
Margaret C. Kline, Erica L. Romsos, David L. Duewer \\ Materials Measurement Laboratory \\ National Institute of Standards and Technology \\ Gaithersburg, MD 20899-8390 USA \\ Contact: David.Duewer@nist.gov
}

\section{Supporting Information}

Trevigels of enzyme-cut NIST1 and NIST2 DNAs

Flashgels of enzyme-cut NIST3 and NIST4 DNAs

Exemplar Trevigel of enzyme-cut and sham-cut NIST2 DNA 


\section{NIST1 and NIST2 Trevigels}
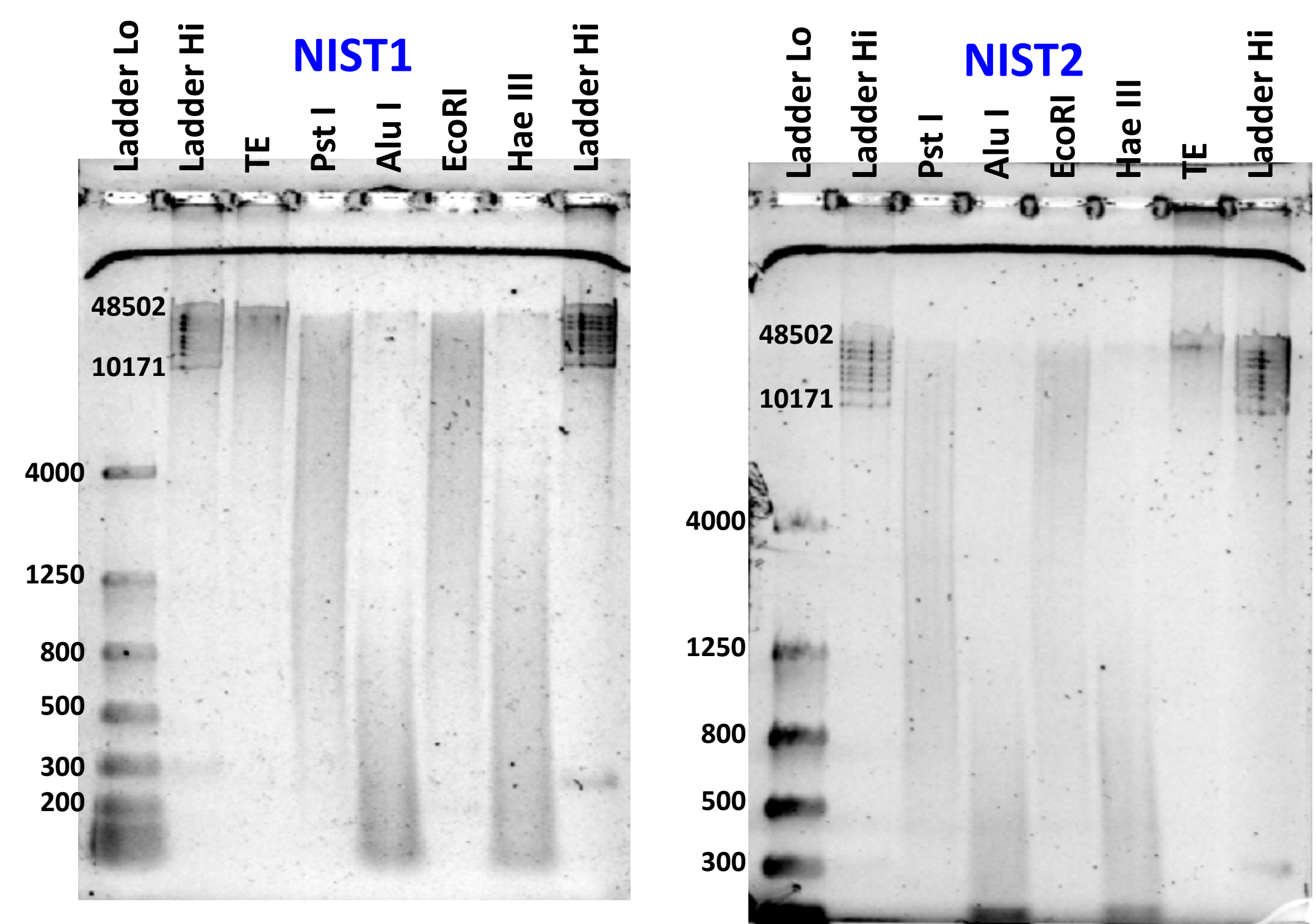
Ladder Lo: Flash gel DNA Marker $100,200,300,500,800,1250,2000,4000$ bp
Ladder Hi: GeneRuler High Range DNA Ladder $10171,12119,13825,15258,17000,20555,24508,48502$ bp Gel Parameters
$0.7 \%$ Trevigel 5000 in 1X TAE Buffer $(0.21 \mathrm{~g})$ $30 \mathrm{~mL}$ gel matrix made microwaved $\approx 1 \mathrm{~m}$
Poured setup 20 min RT
Transfered to $4^{\circ} \mathrm{C}$ for $1 \mathrm{~h}$
TAE buffer also stored at $4{ }^{\circ} \mathrm{C}$
Samples $5 \mu \mathrm{L}$ combined with $6 \mathrm{X}$ Loading buffer
Stained 20 min with SybrGreen I gel stain

High-resolution Trevigels were used to confirm that the uncut TE DNAs were little fragmented and that the enzymecut samples were thoroughly and characteristically fragmented. 


\section{NIST3 and NIST4 FlashGels}

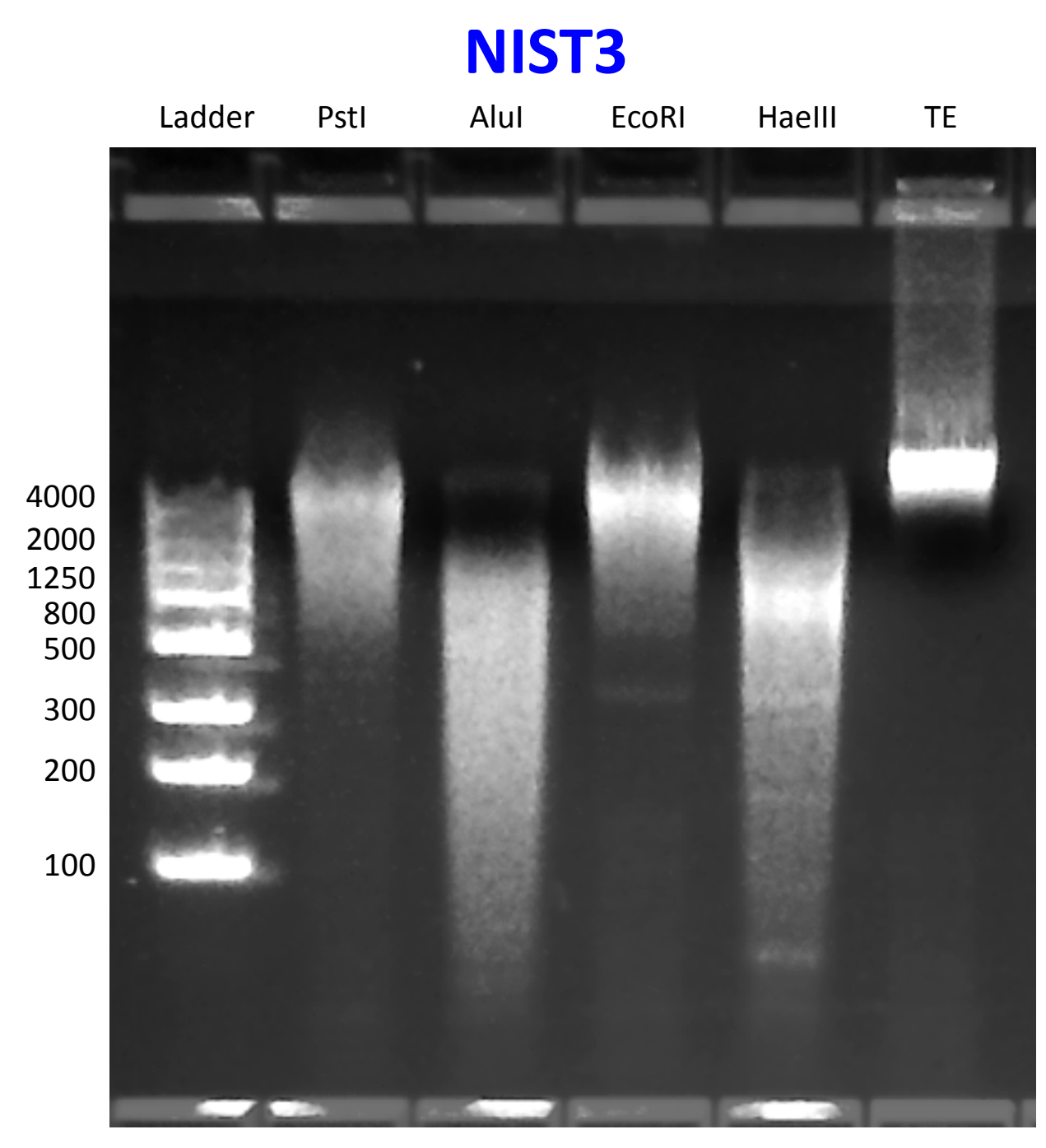

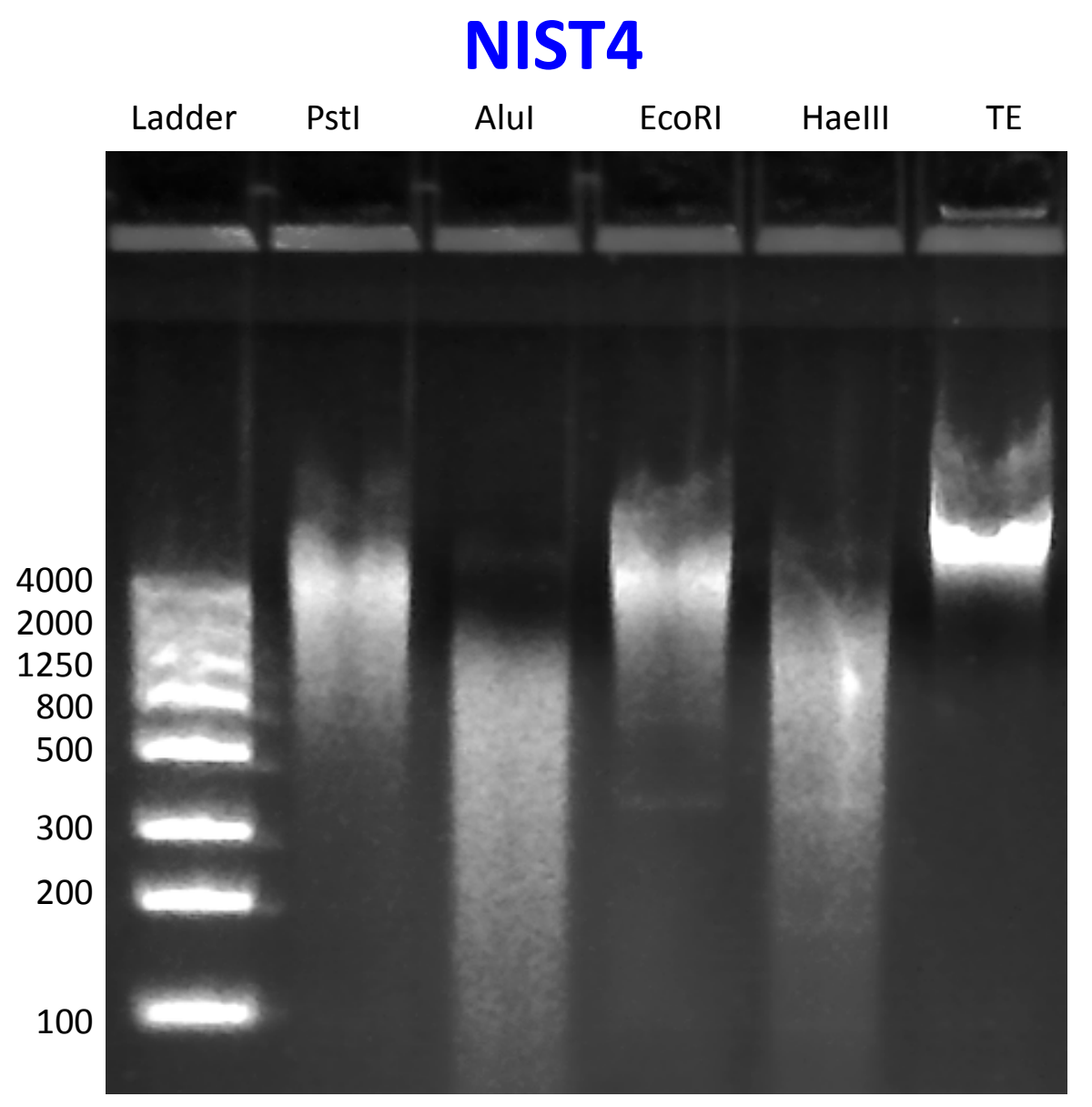

Having confirmed that the uncut TE DNAs were little fragmented, these limited resolution Flashgels were used to confirm that the enzyme-cut samples were thoroughly and characteristically fragmented. 


\section{Exemplar Trevigel of Cut and Sham-cut Samples}

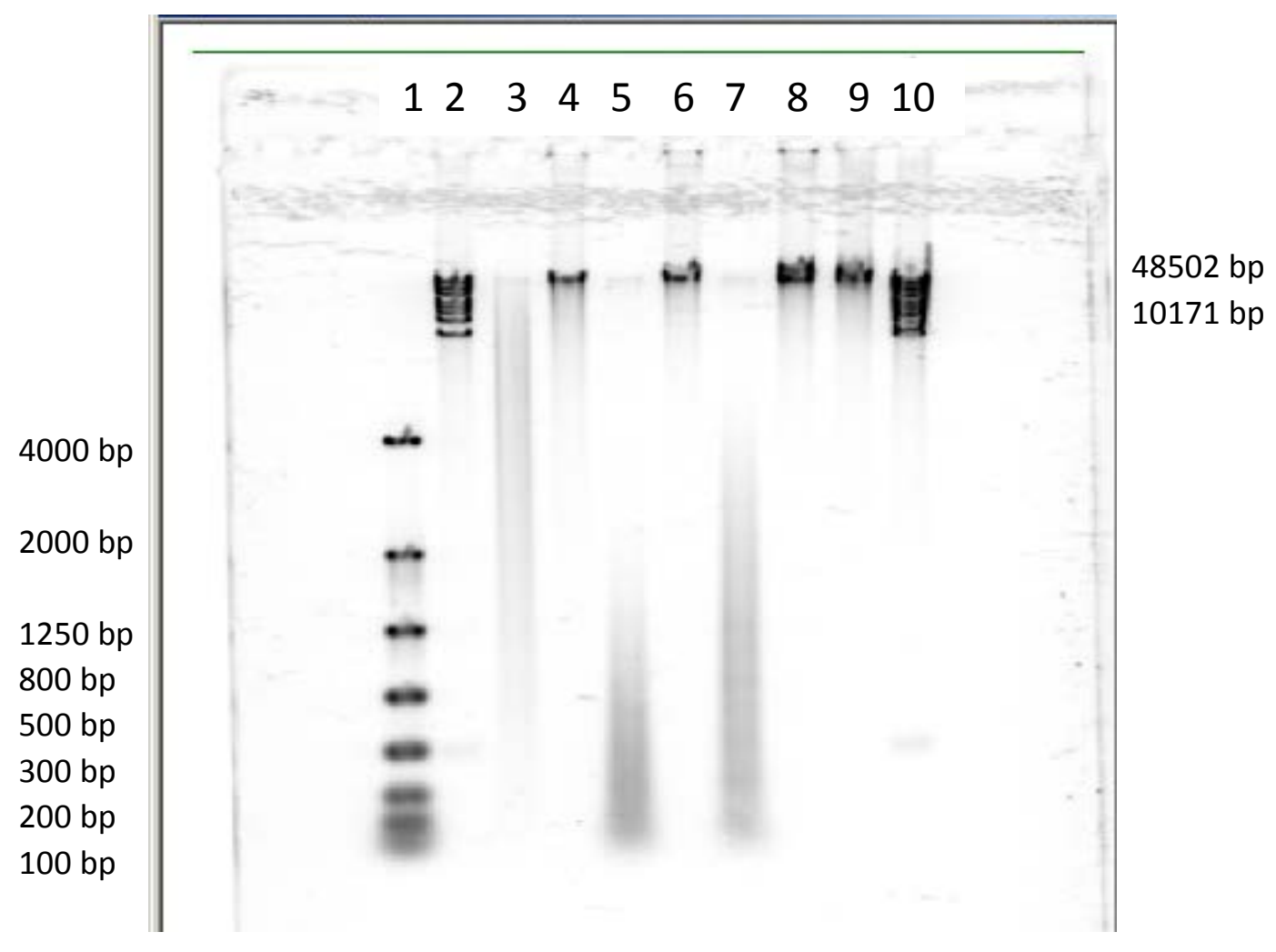

Cut samples: Enzyme-restricted NIST2 DNA

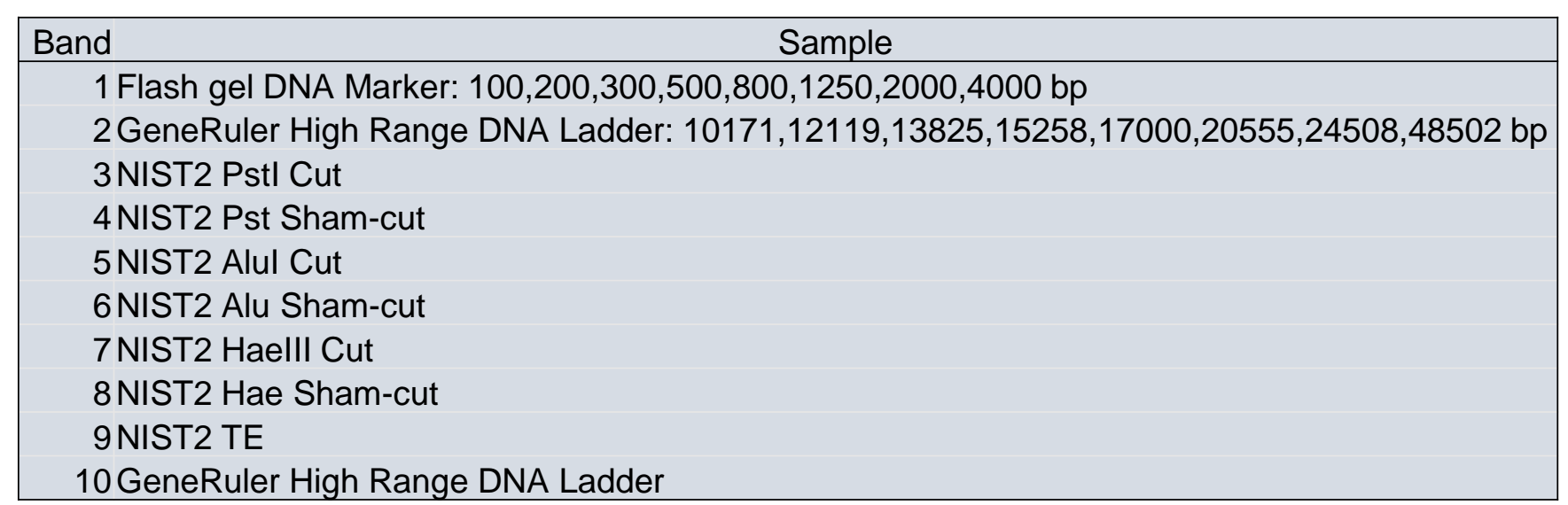

Gel Parameters

$0.7 \%$ Trevigel 5000 in 1 X TAE Buffer $(0.21 \mathrm{~g})$ $30 \mathrm{~mL}$ gel matrix made

microwaved $\approx 1 \mathrm{~m}$

Poured setup $20 \mathrm{~min}$ RT

Transfered to $4{ }^{\circ} \mathrm{C}$ for $1 \mathrm{~h}$

TAE buffer also stored at $4{ }^{\circ} \mathrm{C}$

Samples $5 \mu \mathrm{L}$ combined with $6 \mathrm{X}$ Loading buffer

Run @ 45 V for 130 min

Stained 20 min with SybrGreen I gel stain

Sham-cut Samples: NIST2 DNA manipulated in identical manner, but using

heat-deactivated enzyme 